\title{
ANALISIS PERSEPSI MAHASISWA AKUNTANSI TERHADAP IMPLEMENTASI INTERNASIONAL STANDARDS ON AUDITING (ISA) DI PERGURUAN TINGGI NEGERI DAN PERGURUAN TINGGI SWASTA PURWOKERTO
}

\author{
Kurniawan Dwi Saputra ${ }^{1}$, Atiek Sri Purwati ${ }^{2}$, Syaiful Azhar ${ }^{3}$, Pretisila $^{2}$ \\ Kartika Putri ${ }^{4}$ \\ Jurusan Akuntansi, Fakultas Ekonomi dan Bisnis, UNSOED $D^{1,2,3,4}$ \\ Email corresponding author : kurniawands@outlook.com
}

\begin{abstract}
The title of this research is Analysis of Accounting Student Perceptions on the Implementation of International Standards on Auditing (ISA) in state and private university of Purwokerto. The purpose of the research was to examine the perceptions of accounting students in state and private university of Purwokerto about the implementation of International Standards on Auditing (ISA). This research was conducted by distributing questionnaires to Accounting Student in Purwokerto. The analytical method used is one sample t-test and independent sample t-test. The results of the research show that accounting students in state and private university of Purwokerto have the same perception regarding the implementation of International Standards on Auditing (ISA), and it has been implemented effectively.
\end{abstract}

Keyword: International Standards on Auditing (ISA), Implementation, Perceptions, Accounting student

\begin{abstract}
ABSTRAK
Penelitian ini berjudul Analisis Persepsi Mahasiswa Akuntansi terhadap Implementasi International Standards on Auditing (ISA) di Perguruan Tinggi Negeri dan Swasta Purwokerto. Penelitian ini bertujuan untuk menguji secara empiris tentang persepsi mahasiswa akuntansi perguruan tinggi negeri dan perguruan tinggi swasta di Purwokerto mengenai implementasi International Standards on Auditing (ISA). Penelitian ini dilakukan dengan menggunakan kuesioner yang dibagikan kepada mahasiswa akuntansi Perguruan Tinggi Negeri dan Perguruan Tinggi Swasta Purwokerto. Metode analisis yang digunakan dalam penelitian ini adalah one sample t-test dan independent sample ttest.Hasil penelitian menunjukkan mahasiswa akuntansi perguruan tinggi negeri dan perguruan tinggi swasta di Purwokerto memiliki persepsi yang sama mengenai implementasi International Standards on Auditing (ISA). Mahasiswa akuntansi perguruan tinggi negeri dan perguruan tinggi swasta di Purwokerto mempersepsikan bahwa International Standards on Auditing (ISA) telah diterapkan secara efektif.
\end{abstract}

Kata kunci: International Standards on Auditing (ISA), Implementasi, Persepsi, Mahasiswa Akuntansi.

\section{PENDAHULUAN}

Audit sebuah laporan keuangan adalah kebutuhan bagi setiap perusahaan, karena dengan penilaian auditor independen, laporan keuangan yang dibuat oleh manajemen perusahaan mendapatkan kepercayaan dari pihak yang berkepentingan. Namun keraguan teradap profesi akuntan publik semakin 
meningkat karena banyaknya kasus kegagalan audit atas laporan keuangan. Sebagai contohnya kasus kegagalan audit atas laporan keuangan PT. Indosat, Tbk tahun 2011 oleh KAP Purwantono, Suherman \& Surja dari Ernst \& Young Indonesia, dalam kasus ini KAP Purwantono, Suherman \& Surja dikenakan sanksi sebesar $\$ 1000.000$ oleh Public Company Accounting Oversight Board (PCAOB) lembaga pengawas praktik audit terhadap perusahaan publik guna melindungi investor, sanksi diberikan atas KAP Purwantono, Suherman \& Surja dalam kegagalannya dalam menyajikan bukti yang pendukung dalam perhitungan atas sewa 4.000 menara seluler yang terdapat dalam laporan keuangan PT Indosat, Tbk. Mereka malah memberikan label Wajar Tanpa Pengecualian (WTP) terhadap laporan keuangan tersebut, padahal perhitungan dan analisisnya belum selesai. Auditor dan KPP diharapkan dapat bertanggung jawab atas opini yang dibuat sesuai peraturan dan ketentuan yang berlaku (Andriani, 2018). Dari kejadian tersebut terdapat kesalahan dalam menyampaikan opini audit yang diberikan atas laporan keuangan PT. Indosat, Tbk, hal ini mengindikasikan bahwa auditor lelah lalai dalam menerapkan prinsip audit due professional care, yaitu dalam pelaksanaan audit dan penyusunan laporannya wajib menggunakan kemahiran profesionalismenya dalam cermat dan seksama. Jika auditor dalam melakukan tugasnya tidak cermat serta seksama dalam menyusun laporannya maka telah terjadi penyimpangan terhadap standar audit yang diterapkan, sehingga akan menurunkan kualitas auditnya.

Dalam penelitian yang dilakukan oleh Harahap, et al (2017), Rizkhyana (2017), Husni (2010), dan Khusumawardhani (2015), Standar Audit berbasis International Standards on Auditing (ISA) berpengaruh signifikan terhadap kualitas audit, sehingga diharapkan International Standards on Auditing (ISA) dapat meningkatkan kualitas audit. Pada kenyataan yang terdapat di lapangan, menurut Caecilia dan Rustiana (2016) dalam Pemetaan Penerapan Standar Audit berbasis International Standards on Auditing (ISA) pada Kantor Akuntan Publik (KAP) di Daerah Istimewa Yogyakarta menjelaskan hanya sekitar 17\% dari total KAP yang di teliti sudah menerapkan International Standards on Auditing (ISA), sedangkan sisanya yaitu sekitar 50\% masih sebatas tahu, dan sekitar 33\% masih dalam proses pembelajaran.

Penelitian terhadap penerapan International Standards on Auditing (ISA) di Indonesia belum banyak dilakukan, sedangkan penerapan International Standards on Auditing (ISA) di Indonesia harus terus dimaksimalkan, guna untuk meningkatkan kualitas audit dan auditor. Andriani (2018) telah melakukan penelitian analisis persepsi auditor mengenai implementasi International Standards on Auditing (ISA) terhadap kualitas audit pada kantor akuntan publik (KAP) di Bekasi. Namun pada penelitian ini difokuskan pada persepsi mahasiswa akuntansi terhadap implementasi International Standards on Auditing (ISA) di perguruan tinggi negeri dan perguruan tinggi swasta Purwokerto.

Mahasiswa akuntansi yang merupakan calon akuntan dimasa yang akan datang, tentunya tidak luput menjadi perhatian tentang bagaimana persepsi mereka terhadap implementasi International Standards on Auditing (ISA) di Indonesia. Persepsi serta pemahaman mereka menjadi salah satu tolak ukur untuk melihat perkembangan implementasi International Standards on Auditing (ISA) dan kualitas audit di masa yang akan datang, sehingga ketika mahasiswa akuntansi mendapatkan gelar sarjana, mereka sudah benar-benar siap untuk terjun 
ke dunia kerja dan siap untuk segera menerapkan standar audit berbasis International Standards on Auditing (ISA) dalam pekerjaan auditnya.

Dari fenomena gap dan research gap diatas, memotivasi untuk melakukan penelitian dengan judul "Analisa Persepsi Mahasiswa Akuntansi terhadap Implementasi International Standards on Auditing (ISA) di Perguruan Tinggi Negeri dan Perguruan Tinggi Swasta Purwokerto".

Berdasarkan latar belakang diatas, penelitian ini memiliki beberapa tujuan yang ingin dicapai, beberapa diantaranya adalah:

1. Untuk menguji secara empiris apakah mahasiswa akuntansi perguruan tinggi negeri dan swasta Purwokerto mempunyai persepsi yang sama tentang implementasi International Standards on Auditing (ISA) di Indonesia.

2. Untuk menguji secara empiris apakah mahasiswa akuntansi perguruan tinggi negeri dan swasta Purwokerto mempersepsikan International Standards on Auditing (ISA) telah diimplementasikan di Indonesia.

\section{TELAAH TEORI DAN PERUMUSAN HIPOTESIS}

\section{Teori Persepsi}

Pengertian menurut Hochberg (1984) adalah pengalaman perolehan pancaindra, informasi tentang orang-orang, benda-benda, dan peristiwa-peristiwa serta proses-proses kejiwaan untuk menyempurnakan informasi tersebut. Kreitner dan Angelo (2003) telah menjelaskan bahwa persepsi merupakan proses kognitif yang memungkinkan kita dapat menafsirkan dan memahami lingkungan di sekitar kita. Penafsiran tersebut merupakan pandangan kita tentang lingkungan atau tempat di mana kita berada. Sedangkan pengertian persepsi menurut Writtig (1977) adalah proses penginterpretasian seseorang terhadap stimulus sensori. Proses-proses sensori ini hanya melaporkan tentang lingkungan stimulasi. Kemudian persepsi diterjemahkan pesan sensori ini dalam bentuk-bentuk yang dapat dipahami.

\section{Teori Behavior}

Teori behavior menjelaskan proses terjadinya perilaku manusia yang dipengaruhi banyak faktor. Perilaku merupakan tanggapan manusia sebagai hasil dari belajar. Perilaku ini kemudian dijadikan reaksi dari stimulus yang diberikan. Behaviorisme tidak mau mempersoalkan apakah manusia baik atau jelek, rasional atau emosional, behaviorisme hanya ingin mengetahui bagaimana perilakunya dikendalikan oleh faktor-faktor lingkungan. Dalam arti teori belajar yang lebih menekankan pada tingkah laku manusia. Memandang individu sebagai makhluk reaktif yang memberi respon terhadap lingkungan (Muhith dan Siyoto, 2018). Belajar merupakan akibat adanya interaksi antara stimulus dan respon (Slavin, 2000).

\section{Implementasi}

Kamus Besar Bahasa Indonesia menjelaskan dengan implementasi adalah "Pelaksanaan; penerapan". Implementasi merupakan suatu proses yang dinamis, di mana pelaksanaan kebijakan melalui aktivitas atau kegiatan, sehingga pada akhirnya akan mendapat suatu hasil yang sesuai dengan tujuan atau sasaran kebijakan itu sendiri (Khusumawardhani, 2015). Implementasi adalah tindakantindakan yang dilakukan baik oleh individu-individu, pejabat-pejabat, atau 
kelompok-kelompok pemerintah atau swasta yang diarahkan pada tercapainya tujuan-tujuan yang telah digariskan dalam keputusan kebijakan (Wahab, 2008).

\section{Audit dan Profesi Auditor}

Audit ialah suatu proses sistematis untuk memperoleh dan mengevaluasi bukti secara objektif mengenai pernyataan-pernyataan tentang kegiatan dan kejadian ekonomi dengan tujuan untuk menetapkan tingkat kesesuaian antara pernyataan-pernyataan tersebut dengan kriteria yang telah ditetapkan dan penyampaian hasil-hasilnya kepada pemakai yang berkepentingan (Mulyadi, 2002). Dapat disimpulkan bahwa audit adalah kegiatan sistematis yang dilakukan oleh pihak independen untuk menilai dan mengevaluasi terhadap seberapa jauh kesesuaian bukti atas kejadian-kejadian ekonomi, kemudian atas dasar penilaian tersebut, akan diberikan pendapat kesesuaian oleh pihak independen.

Keberadaan profesi auditor publik telah diakui secara resmi oleh pemerintah melalu undang-undang No. 34 tahun 1954 tentang pemakaian gelar akuntan. Untuk meningkatkan mutu profesi akuntan publik, maka disusunlah standar Profesional Akuntan Publik (SPAP) dan Kode Etik Akuntan yang merupakan panduan setiap akuntan publik dalam menjalankan profesinya. Profesi akuntan publik memegang peranan penting dalam perkembangan bisnis global dewasa ini. Alasannya karena profesi akuntan publik inilah yang berkompeten memberikan pendapat atas kewajaran laporan keuangan.

\section{Standar Audit ISA}

Standar audit merupakan pedoman audit atas laporan keuangan historis. Standar audit berbeda dengan prosedur audit. prosedur menyangkut langkahlangkah yang harus dilaksanakan, sedangkan standar audit berkenaan dengan kriteria atau ukuran mutu pelaksanaan serta dikaitkan dengan tujuan yang hendak dicapai dengan menggunakan prosedur yang bersangkutan

Keberadaan International Standards on Auditing (ISA) sebagai standar yang digunakan dalam audit atas informasi keuangan historis sudah cukup lama, sejak tahun 1991. Pada tahun 2004 IAASB memulai program yang komprehensif untuk meningkatkan kejelasan atas International Standards on Auditing (ISA) yang dikenal sebagai Clarity Project. Dalam program ini IAASB menerapkan konvensi baru mengenai penyusunan draft pada seluruh International Standards on Auditing (ISA), sebagai bagian dari revisi substantif maupun penyusunan draf ulang secara terbatas. Tanggal 27 Februari 2009, IAASB telah diselesaikannya Clarity Project tersebut. Dengan demikian, International Standards on Auditing (ISA) yang terbit pasca selesainya Clarity Project tampil sesuai dengan konvensi yang baru. Hasil dari Clarity Project yakni adanya 36 International Standards on Auditing (ISA) baru yang sudah dimutakhirkan dan diklarifikasi dan 1 ISQC yang sudah diklarifikasi (Tuanakotta, 2013).

\section{Kualitas Audit}

Kualitas audit dapat diartikan sebagai bagus atau tidaknya suatu pemeriksaan yang telah dilakukan oleh auditor. Berdasarkan Standar Profesi Akuntan Publik (SPAP) audit yang dilaksanakan auditor dikatakan berkualitas, jika memenuhi ketentuan atau standar pengauditan. Standar pengauditan 
mencakup mutu profesional, auditor independen, pertimbangan (judgement) yang digunakan dalam pelaksanaan audit dan penyusunan laporan audit.

\section{Perumusan Hipotesis}

Dari kajian teori tersebut diatas, maka hipotesis yang diajukan adalah:

$\mathrm{H}_{1}$ : Mahasiswa akuntansi perguruan tinggi negeri dan perguruan tinggi swasta Purwokerto mempunyai persepsi yang sama tentang implementasi International Standards on Auditing (ISA) di Indonesia.

$\mathrm{H}_{2}$ : Mahasiswa akuntansi perguruan tinggi negeri dan swasta Purwokerto mempersepsikan International Standards on Auditing (ISA) telah diimplementasikan secara efektif.

\section{METODE PENEITIAN}

\section{Populasi dan Sampel}

Penelitian ini adalah penelitian kuantitatif. Objek penelitian ini adalah implementasi International Standards on Auditing (ISA) dan persepsi mahasiswa akuntansi perguruan tinggi negeri dan perguruan tinggi swasta di Purwokerto. Populasi dalam penelitian ini dipilih berdasarkan kriteria berikut:

1. Mahasiswa jurusan akuntansi di perguruan tinggi negeri dan perguruan tinggi swasta Purwokerto

2. Dalam periode penelitian, responden kuesioner penelitian telah menempuh mata kuliah audit.

3. Mahasiswa aktif tahun angkatan 2016.

Penetapan sampel dalam penelitian ini akan dihitung menggunakan rumus Slovin. Berikut adalah rumus yang digunakan:

$n=\frac{N}{1+N e^{2}}$

Keterangan:

n: Jumlah sampel

$\mathrm{N}$ : Jumlah populasi

e: Batas toleransi kesalahan $5 \%$.

Berdasarkan rumus diatas dan setelah mengetahui jumlah populasi maka sampel yang akan diambil dalam penelitian ini adalah sebagai berikut:

$n=\frac{240}{1+240(0.05)^{2}}=\frac{240}{1.6}=150$ mahasiswa

Catatan: jika dalam sebuah kelas mata kuliah audit yang ideal diasumsikan terdapat sekitar 40 mahasiswa dan setiap perguruan tinggi memiliki 2 kelas dalam satu angkatan.

\section{Teknik Pengambilan Data}

Penelitian ini akan menggunakan teknik convenience sampling, yaitu teknik pengambilan sampel dengan cara menyebar sejumlah kuesioner dan menggunakan kuesioner yang kembali dan dapat diolah. Metode respon yang digunakan peneliti adalah skala Likert, yang menggunakan ukuran ordinal sebagai nilai skalanya. Selanjutnya skor penilaian jawaban untuk pertanyaan tersebut adalah Sangat tidak setuju $(\mathrm{STS})=$ skor 1 , tidak setuju $(\mathrm{TS})=\operatorname{skor} 2$, Ragu $(\mathrm{R})=\operatorname{skor} 3$, Setuju $(\mathrm{S})=$ skor 4 dan Sangat Setuju (SS) = skor 5 . 


\section{Teknik Analisa Data}

Penelitian ini menggunakan kuesioner dan independent sample t-test, sehingga diperlukan pengujian berikut ini:

1. Uji Validitas menggunakan teknik korelasi product moment Apabila nilai $r_{\text {hitung }} \geq r_{\text {tabel }}$ maka skor butir kuesioner dinyatakan valid. Sebaliknya jika nilai $r_{\text {hitung }}<r_{\text {tabel }}$ maka skor butir kuesioner tidak valid.

2. Uji Reliabilitas menggunakan teknik Cronbach Alpha. Menurut Ghozali (2015), instrumen memiliki tingkat reliabilitas yang tinggi apabila nilai koefisien Cronbach Alpha yang diperoleh > 0,60.

3. Uji Normalitas dilakukan dengan uji statistik Kolmogorov-Smirnov Test. Residual berdistribusi normal jika memiliki signifikasi $\geq 0.05 \%$ (Ghozali, 2011).

4. Uji Statistik Deskriptif adalah bagian dari statistik yang mempelajari cara pengumpulan data dan penyajian sehingga mudah dipahami (Hasan, 2004). Terdiri dari nilai minimum, nilai maksimum, rata-rata dan standar deviasi.

5. Uji Hipotesis I menggunakan alat statistik independent sample t-test (pooled varians $t$-test). Jika $\mathrm{t}_{\text {hitung }} \geq-\mathrm{t}_{\text {tabel }}$, tidak menolak $\mathrm{H}_{0}$, namun jika $\mathrm{t}_{\text {hitung }}<-\mathrm{t}$ tabel, maka tidak menerima $\mathrm{H}_{0}$.

6. Uji Hipotesis II menggunakan alat statistik t-test satu sampel atau one sample $t$-test. Jika $\mathrm{t}_{\text {hitung }} \geq \mathrm{t}_{\text {tabel }}$, tidak menolak $\mathrm{H}_{0}$, namun jika $\mathrm{t}_{\text {hitung }}<\mathrm{t}_{\text {tabel }}$ , maka tidak menerima $\mathrm{H}_{0}$.

\section{HASIL DAN PEMBAHASAN}

\section{Deskripsi Responden}

Responden dalam penelitian ini adalah mahasiswa akuntansi perguruan tinggi negeri dan perguruan tinggi swasta di Purwokerto, sehingga lokasi penelitian ini bertempat pada beberapa perguruan tinggi negeri dan perguruan tinggi swasta yang terletak di Purwokerto. Responden penelitian ini berjumlah 150 orang. Sebanyak 126 kuesioner berhasil kembali dan dapat di olah, sedangkan sisanya sebanyak 24 kuesioner tidak sesuai kriteria, karena kuesioner belum terisi seluruhnya atau terdapat kerusakan pada kuesioner. Tingkat partisipasi responden adalah sebesar $84 \%$, terdistribusikan berdasarkan asal perguruan tinggi seperti pada table dibawah ini:

Tabel 1. Distribusi responden berdasarkan asal perguruan tinggi

\begin{tabular}{lcc}
\hline Asal Perguruan tinggi & Responden & Persentase (\%) \\
\hline Perguruan Tinggi Negeri & 69 orang & 54,8 \\
Perguruan Tinggi Swasta & 57 orang & 45,2 \\
\hline JUMLAH & 126 orang & 100,0 \\
\hline
\end{tabular}

Sedangkan berdasarkan jenis kelamin sebagai berikut:

Tabel 2. Distribusi responden berdasarkan jenis kelamin

\begin{tabular}{lcc}
\hline Jenis Kelamin & Responden & Persentase (\%) \\
\hline Laki-laki & 48 orang & 38,1 \\
Perempuan & 69 orang & 54,7 \\
Tanpa Keterangan & 9 orang & 7,2 \\
\hline JUMLAH & 126 orang & 100,0 \\
\hline \hline \multicolumn{1}{c}{$\mathbf{1 7 4}$} & & Saputra ${ }^{1}$, Purwati $^{2}$, Azhar $^{3}$, Putri $^{4}$
\end{tabular}




\section{Uji Validitas}

Pengujian validitas dengan nilai $\mathrm{t}$ table sebesar 0,468 untuk semua butir pertanyaan dikatakan valid. Hasil Pengujian untuk setiap indikator dapat dilihat pada tabel dibawah ini:

Tabel 3. Uji validitas prinsip-prinsip umum dan tanggung jawab

\begin{tabular}{ccc}
\hline Ins & $\mathbf{r}_{\text {hitung }}$ & Kesimpulan \\
\hline q1 & 0.671 & Valid \\
q2 & 0.659 & Valid \\
q3 & 0.474 & Valid \\
q4 & 0.674 & Valid \\
q5 & 0.825 & Valid \\
q6 & 0.618 & Valid \\
q7 & 0.680 & Valid \\
q8 & 0.786 & Valid \\
\hline
\end{tabular}

Tabel 4. Uji validitas penilaian risiko dan respons terhadap risiko yang telah

\begin{tabular}{ccc}
\hline Ins & $\mathbf{r}_{\text {hitung }}$ & Kesimpulan \\
\hline $\mathrm{q} 9$ & 0.921 & Valid \\
q10 & 0.799 & Valid \\
q11 & 0.785 & Valid \\
q12 & 0.493 & Valid \\
q13 & 0.741 & Valid \\
q14 & 0.567 & Valid \\
\hline
\end{tabular}

Tabel 5. Uji validitas bukti audit

\begin{tabular}{ccc}
\hline Ins & $\mathbf{r}_{\text {hitung }}$ & Kesimpulan \\
\hline q15 & 0.529 & Valid \\
q16 & 0.829 & Valid \\
q17 & 0.549 & Valid \\
q18 & 0.553 & Valid \\
q19 & 0.753 & Valid \\
q20 & 0.578 & Valid \\
q21 & 0.815 & Valid \\
q22 & 0.540 & Valid \\
q23 & 0.698 & Valid \\
q24 & 0.722 & Valid \\
q25 & 0.804 & Valid \\
\hline
\end{tabular}


Tabel 6. Uji validitas penggunaan pekerjaan pihak lain

\begin{tabular}{ccc}
\hline Ins & $\mathbf{r}_{\text {hitung }}$ & kesimpulan \\
\hline q26 & 0.845 & Valid \\
q27 & 0.471 & Valid \\
q28 & 0.663 & Valid \\
\hline
\end{tabular}

Tabel 7. Uji validitas kesimpulan audit dan pelaporan

\begin{tabular}{ccc}
\hline Ins & $\mathbf{r}_{\text {hitung }}$ & Kesimpulan \\
\hline q29 & 0.576 & Valid \\
q30 & 0.607 & Valid \\
q31 & 0.482 & Valid \\
q32 & 0.696 & Valid \\
q33 & 0.642 & Valid \\
\hline
\end{tabular}

Tabel 8. Uji validitas area-area khusus

\begin{tabular}{ccc}
\hline Ins & $\mathbf{r}_{\text {hitung }}$ & Kesimpulan \\
\hline q34 & 0.816 & Valid \\
q35 & 0.653 & Valid \\
q36 & 0.848 & Valid \\
\hline
\end{tabular}

Tabel 9. Uji validitas kesesuaian pemeriksaan dengan standar audit

\begin{tabular}{ccc}
\hline Ins & $\mathbf{r}_{\text {hitung }}$ & kesimpulan \\
\hline $\mathrm{q} 37$ & 0.484 & Valid \\
q38 & 0.614 & Valid \\
q39 & 0.577 & Valid \\
q40 & 0.693 & Valid \\
q41 & 0.477 & Valid \\
q42 & 0.473 & Valid \\
q43 & 0.718 & Valid \\
q44 & 0.476 & Valid \\
q45 & 0.799 & Valid \\
q46 & 0.690 & Valid \\
q47 & 0.659 & Valid \\
q48 & 0.483 & Valid
\end{tabular}




\begin{tabular}{ccc} 
q49 & 0.651 & Valid \\
\hline & Tabel 10. Uji validitas kualitas laporan hasil audit \\
\hline Ins & $\mathbf{r}_{\text {hitung }}$ & kesimpulan \\
\hline q50 & 0.772 & Valid \\
q51 & 0.674 & Valid \\
q52 & 0.856 & Valid \\
q53 & 0.680 & Valid \\
q54 & 0.844 & Valid \\
q55 & 0.854 & Valid \\
q56 & 0.825 & Valid \\
\hline
\end{tabular}

\section{Uji Reliabilitas}

Tabel dibawah merupakan ringkasan hasil pengujian reliabilitas, dapat diketahui bahwa nilai koefisien Cronbach-Alpha untuk setiap indikator instrumen penelitian lebih besar dari 0,60. Kesimpulan yang dapat diambil dari hasil diatas adalah seluruh instrumen pada penelitian ini dapat dikatakan reliabel.

Tabel 11. Hasil pengujian reliabilitas

\begin{tabular}{clc}
\hline No. & \multicolumn{1}{c}{ Indikator } & Koefisien Cronbach-Alpha \\
\hline 1 & Prinsip-prinsip umum dan tanggung jawab & 0.764 \\
2 & Penilaian risiko dan respon terhadap risiko & 0.783 \\
3 & yang telah dinilai & 0.764 \\
4 & Bukti audit & 0.740 \\
5 & Penggunaan pekerjaan pihak lain & 0.725 \\
6 & Area-area khusus & 0.815 \\
7 & Kesesuaian pemeriksaan dengan standar & 0.751 \\
8 & audit & 0.791 \\
\hline
\end{tabular}

\section{Uji Normalitas}

Suatu data dikatakan berdistribusi normal apabila nilai signifikansinya lebih besar dari 0,05. Berdasarkan hasil pengujian menggunakan Kolmogorov-Smirnov, diketahui nilai Asymp. Sig. sebesar 0,200 yaitu lebih besar dari pada nilai signifikasinya, sehingga dapat dikatakan data berdistribusi normal. Sehingga pengujian dilakukan dengan menggunakan uji statistik parametrik.

\section{Uji Statistik Deskriptif}

Analisis statistik deskriptif memberikan gambaran mengenai variabel penelitian berdasarkan nilai minimum, nilai maksimum, rata-rata (mean) dan simpangan baku (standar deviation). Statistik deskriptif selengkapnya dapat dilihat pada tabel berikut: 
Tabel 12. Hasil analisis deskriptif

\begin{tabular}{ccccccc}
\hline Indikator & $\mathbf{N}$ & $\begin{array}{c}\text { Minimu } \\
\text { m }\end{array}$ & $\begin{array}{c}\text { Maksimu } \\
\mathbf{m}\end{array}$ & Mean & Mean/item & $\begin{array}{c}\text { Std. } \\
\text { Deviation }\end{array}$ \\
\hline A & 126 & 27 & 40 & 33,34 & 4,16 & 2,36 \\
B & 126 & 18 & 30 & 25,13 & 4,18 & 2,56 \\
C & 126 & 39 & 54 & 44,28 & 4,02 & 3,34 \\
D & 126 & 7 & 15 & 11,75 & 3,91 & 1,52 \\
E & 126 & 14 & 25 & 19,73 & 3,94 & 2,29 \\
F & 126 & 8 & 15 & 11,77 & 3,92 & 1,46 \\
G & 126 & 43 & 63 & 53,68 & 4,12 & 3,83 \\
H & 126 & 22 & 35 & 29,01 & 4,14 & 2,47 \\
Valid N & 126 & & & & & \\
\hline
\end{tabular}

Keterangan indikator :

A: Prinsip-prinsip umum dan tanggung jawab

B: Penilaian risiko dan respon terhadap risiko yang telah dinilai

C : Bukti audit

D : Penggunaan pekerjaan pihak lain

E : Kesimpulan audit dan pelaporan

$\mathrm{F}$ : Area-area khusus

$\mathrm{G}$ : Kesesuaian pemeriksaan dengan standar audit

$\mathrm{H}$ : Kualitas laporan hasil audit

\section{Uji Hipotesis I}

Berdasarkan hasil SPSS diketahui nilai $\mathrm{t}_{\text {hitung }}(0,531)$ lebih besar dari pada nilai $-\mathrm{t}$ tabel $(-1,657)$, sehingga dapat disimpulkan bahwa $\mathrm{H}_{0}$ diterima, yang artinya persepsi mahasiswa akuntansi perguruan tinggi negeri sama dengan persepsi mahasiswa perguruan tinggi swasta Purwokerto secara signifikan.

Tabel 13. Ringkasan hasil independent sampel t-test

\begin{tabular}{lcccc}
\hline \multicolumn{1}{c}{ Hipotesis $\left(\mathbf{H}_{\mathbf{0}}\right)$} & df & $\mathbf{t}_{\text {hitung }}$ & $\mathbf{t}_{\text {tabel }}$ & Keterangan \\
\hline $\begin{array}{l}\text { Mahasiswa Perguruan Tinggi Negeri dan Mahasiswa } \\
\text { Perguruan Tinggi Swasta Purwokerto memiliki }\end{array}$ & & & & \\
$\begin{array}{l}\text { persepsi yang sama tentang implementasi International } \\
\text { Standards on Auditing (ISA) }\end{array}$ & 124 & 0,531 & 1,657 & Diterima \\
\hline
\end{tabular}

\section{Uji Hipotesis II}

Berdasarkan hasil SPSS diketahui nilai $\mathrm{t}_{\text {hitung }}(4,692)$ lebih besar dari nilai $\mathrm{t}$ tabel $(1,657)$, sehingga dapat disimpulkan bahwa $\mathrm{H}_{0}$ diterima, yang artinya mahasiswa akuntansi perguruan tinggi negeri dan perguruan tinggi swasta Purwokerto mempersepsikan International Standards on Auditing (ISA) telah implementasikan secara efektif.

Tabel 14. Ringkasan hasil one sampel t-test

\begin{tabular}{lcccc}
\hline \multicolumn{1}{c}{ Hipotesis $\left(\mathbf{H}_{\mathbf{0}}\right)$} & df & $\mathbf{t}_{\text {hitung }}$ & $\mathbf{t}_{\text {tabel }}$ & Keterangan \\
\hline $\begin{array}{l}\text { Mahasiswa akuntansi perguruan tinggi negeri dan } \\
\text { perguruan tinggi swasta mempersepsikan bahwa }\end{array}$ & & & & \\
$\begin{array}{l}\text { International Standards on Auditing (ISA) telah } \\
\text { diimplementasikan secara efektif }\end{array}$ & 124 & 4.692 & 1,657 & Diterima \\
\hline
\end{tabular}




\section{Pembahasan}

Hasil penelitian menunjukkan bahwa mahasiswa akuntansi perguruan tinggi negeri dan perguruan tinggi swasta di Purwokerto mempunyai persepsi yang sama tentang implementasi International Standards on Auditing (ISA) di Indonesia. Mahasiswa akuntansi perguruan tinggi di Purwokerto mempersepsikan bahwa penerapan International Standards on Auditing (ISA) telah efektif yang penerapannya dapat mempengaruhi kualitas audit. Persepsi yang sama juga terdapat pada hasil penelitian Harahap et al. (2017) yang menjelaskan bahwa standar audit berbasis International Standards on Auditing (ISA) berpengaruh signifikan terhadap kualitas audit. Persepsi yang timbul dikarenakan adanya proses kognitif yang memungkinkan seorang individu menafsirkan dan memahami lingkungan sekitarnya (Kreitner dan Angelo, 2003). Robbins (2008) menjelaskan bahwa persepsi dipengaruhi oleh banyak faktor. Faktor yang dapat mempengaruhi kesamaan persepsi antara mahasiswa perguruan tinggi negeri dan perguruan tinggi swasta, adalah faktor pada target terhadap latar belakang dan faktor pada pemersepsi terhadap sikap dan pengalaman. Mahasiswa akuntansi perguruan tinggi negeri maupun perguruan tinggi swasta di Purwokerto berlatar belakang pendidikan ekonomi yang di dapatkan dari pendidikan dari kurikulum yang sama walaupun berasal dari institusi yang berbeda, sehingga dapat menimbulkan sikap serta pengalaman yang sama pula. Persepsi mahasiswa akuntansi yang memiliki kesamaan persepsi dengan auditor, dikemudian hari dapat memperlancar mereka dalam proses penerapan International Standards on Auditing (ISA), karena dengan adanya persepsi tersebut diharapkan dapat lebih memotivasi bagi mahasiswa akuntansi untuk senantiasa memperkaya ilmu pengetahuan khususnya di bidang audit, sehingga kelak ketika menjadi auditor mereka siap untuk menerapkan International Standards on Auditing (ISA).

Hasil penelitian menunjukkan bahwa mahasiswa akuntansi di Purwokerto mempersepsikan bahwa penerapan International Standards on Auditing (ISA) telah dilakukan secara efektif, sehingga dapat meningkatkan kualitas audit. Hasil penelitian yang dilakukan Andriani (2018) menunjukkan bahwa persepsi yang sama juga diungkapkan auditor pada KAP di Bekasi yang menyatakan penerapan International Standards on Auditing (ISA) berpengaruh terhadap kualitas audit. Persepsi mahasiswa akuntansi di Purwokerto dan persepsi auditor di KAP Bekasi pada penelitian Andriani (2018) mengenai penerapan International Standards on Auditing (ISA) yang dapat meningkatkan kualitas audit, dapat membuktikan bahwa urgensi dari penerapan International Standards on Auditing (ISA) sangat tinggi sebagai jawaban atas tantangan ekonomi global. Persepsi mahasiswa akuntansi perguruan tinggi negeri dan perguruan tinggi swasta di Purwokerto tidak sesuai dengan hasil penelitian Caecilia dan Rustiana (2016) yang menyebutkan hanya sekitar $17 \%$ dari total KAP yang diteliti yang telah dalam tahap penerapan sedangkan sisanya yaitu 50\% masih sekedar mengetahui saja dan $33 \%$ masih dalam tahap edukasi. Persepsi yang timbul merupakan hasil dari pengalaman dari pemersepsi, persepsi ini tidak mempersoalkan baik atau buruk maupun rasional atau emosional (Muhith dan Siyoto, 2018). Hasil persepsi merupakan hasil tingkah laku pemersepsi, yang merupakan bagian dari hasil perilaku yang di kendalikan oleh faktor-faktor lingkungan dan berdasarkan hasil belajar yang memunculkan perilaku yang di inginkan. Belajar merupakan akibat adanya interaksi antara stimulus dan respon (Slavin, 2000). 
Indonesia mulai menerapkan standar audit berbasis International Standards on Auditing (ISA) pada tanggal 1 Januari 2013 (Nadia, 2013), sehingga masih banyak faktor-faktor yang dapat menghambat proses transisi atau perpindahan dari standar audit sebelumnya ke standar audit berbasis International Standards on Auditing (ISA). Penelitian Caecilia dan Rustiana (2016) menyebutkan bahwa alasan pihak KAP belum melakukan tindakan terkait penerapan International Standards on Auditing (ISA) dikarenakan terkendalanya pihak KAP pada klien mereka yang berukuran kecil dan menengah di mana dalam pelaporannya masih berdasarkan SAK-ETAP. Dibutuhkan pelatihan serta pendidikan bagi para auditor agar penerapan International Standards on Auditing (ISA) segera terwujud, sehingga kualitas audit di Indonesia dapat bersaing di dunia internasional sebagai jawaban tantangan ekonomi global.

\section{KESIMPULAN}

\section{Kesimpulan Penelitian}

Berdasarkan pembahasan diatas, dapat ditarik beberapa kesimpulan dari hasil penelitian yang telah dilakukan sebagai berikut:

1. Mahasiswa akuntansi perguruan tinggi negeri dan perguruan tinggi swasta di Purwokerto memiliki persepsi yang sama mengenai penerapan International Standards on Auditing (ISA).

2. Mahasiswa akuntansi perguruan tinggi negeri dan perguruan tinggi swasta di Purwokerto mempersepsikan bahwa International Standards on Auditing (ISA) telah di implementasikan dengan efektif.

\section{Implikasi}

1. Untuk mengetahui sejauh mana persepsi mahasiswa akuntansi perguruan tinggi negeri dan perguruan tinggi swasta tentang implementasi International Standards on Auditing (ISA) di Indonesia, sehingga dapat memotivasi mahasiswa akuntansi khususnya di Purwokerto agar selalu menambah ilmu serta wawasan yang berkaitan implementasi International Standards on Auditing (ISA).

2. Untuk memberikan pertimbangan kepada Kantor Akuntan Publik (KAP) mengenai sejauh mana persepsi mahasiswa akuntansi perguruan tinggi negeri dan swasta Purwokerto terhadap implementasi International Standards on Auditing (ISA) di Indonesia, sehingga dapat digunakan sebagai bahan pertimbangan dalam memilih akuntan publik yang kompeten dan handal.

\section{Keterbatasan dan Saran}

Partisipasi responden masih rendah dikarenakan kesadaran pentingnya International Standards on Auditing (ISA) masih perlu ditingkatkan. Peneliti mengalami beberapa kali out of planing karena kesulitan membujuk responden untuk mengisi kuesioner. Sebagian dari kuesioner yang kembali tidak dapat diolah, karena beberapa pertanyaan belum terjawab. Sebanyak 54 butir pertanyaan membuat responden mudah merasa bosan sebelum responden menyelesaikan pengisian kuesioner.

Untuk penelitian selanjutnya diharapkan menggunakan jenis penelitian kualitatif dengan menggunakan diskusi dan wawancara untuk memperkaya literasi, sehingga dapat memperjelas hasil analisa serta mengetahui faktor-faktor 
yang dapat mempengaruhi persepsi mahasiswa akuntansi. Hasil penelitian menunjukkan ada hambatan dalam mengimplementasikan International Standards on Auditing (ISA), sehingga penelitian selanjutnya diharapkan dapat menambahkan variabel lain berdasarkan hambatan tersebut, seperti pengaruh proses pendidikan serta pelatihan terhadap persepsi mahasiswa.

\section{DAFTAR PUSTAKA}

Andriani, MC. (2018). Analisis Persepsi Auditor Mengenai Implementasi International Standards on Auditing (ISA) Terhadap Kualitas Audit pada Kantor Akuntan Publik (KAP) di Bekasi.

Caecilia, MAS., Rustiana (2016). Pemetaan Penerapan Standar Audit berbasis ISA pada Kantor Akuntan Publik (KAP) di Daerah Istimewa Yogyakarta. Diakses dari: https://ojs.uajy.ac.id/index.php/modus/article/view/663 (11 November 2018)

Ghozali, I. (2011). Aplikasi Analisis Multivariative dengan Program SPSS. (Edisi Ketiga). Semarang: Badan Penerbit Universitas Diponogoro. . (2015). Aplikasi Analisis Multivariative dengan Program SPSS. (Edisi Keempat). Semarang: Badan Penerbit Universitas Diponogoro.

Harahap., Devianti Y., Suciati, NH., Puspitasari, E., \& Rachmianty, S. (2017). Pengaruh Pelaksanaan Standar Audit Berbasis Internasional Standards on Auditing (ISA) terhadap Kualitas Audit. Jurnal Akuntansi riset. 6, 51-68. Diakses dari: http://ejournal.upi.edu/index.php/aset/article/view/5444 (9 Oktober 2018)

Hasan, MI. (2004). Pokok-Pokok Materi Statistik 1 (Statistik Deskriptif). (Edisi Kedua), Jakarta: PT. Bumi Aksara.

Hochberg, J. (1984). Perception. Encyckopedia of Phychology. New York: John Willey \& Sons,Inc.

Husni, (2010). Pengaruh Independensi dan Standar Auditing Terhadap Kualitas Audit pada Kantor BPK RI Perwakilan provinsi Aceh. Diakses dari http://repository.usu.ac.id/handle/123456789/21498. (28 Oktober 2018)

Kreitner, R., Angelo K. (2003). Perilaku organisasi (Organizational Behavior). Jakarta: Salemba Empat.

Khusumawardhani, AP. (2015). Implementasi International Standards on Auditing (ISA) dan Dampaknya pada kualitas Audit (Studi Kasus di Kantor Akuntan Publik Afiliasi dan Lokal). Diakses dari: https://repository.usd.ac.id/2054/2/112114057_full.pdf (18 Oktober 2018)

Muhith, A., Siyoto, S. 2018. Aplikasi Komunikasi Terapeutik \& Healty. ANDI: Yogyakarta. Diakses dari: https://books.google.co.id/books?id=fL9jDwAAQBAJ\&pg (1 Januari 2019)

Mulyadi. (2002). Auditing Buku 1, (Edisi ke Enam). Jakarta: Salemba Empat.

Nadia (2013). Fakultas Ekonomi dan Bisnis UGM. Diakses dari Universitas Gadjah Mada, Situs web FEB UGM https://feb.ugm.ac.id/id/berita/538standar-audit-internasional-isa-untuk-indonesia (21 Oktober 2018)

Robbins, SP, (2008). Perilaku Organisasi (Buku 2). Jakarta: Salemba Empat.

Rizkhyana, B. (2017). Persepsi Penerapan Standar Audit Berbasis ISA Terhadap Kualitas Audit dengan Pemahaman Etika Sebagai Variabel Moderating (Sumatera 
http://www.digilib.unsri.ac.id/index.php?p=fstreampdf\&fid $=12603 \&$ bid $=13708$. (28 Oktober 2018)

Slavin, R.E. (2000). Educational Psychology: Theory and Practice. Sixth Edition. Boston: Allyn and Bacon

Tuanakotta, TM. (2013). Audit Berbasis ISA (International Standards on Auditing). Jakarta: Salemba Empat.

Undang-undang No. 34 tahun 1954 tentang pemakaian gelar akuntan.

Wahab, SA. (2008). Analisa Kebijakan: Dari Formulasi ke Implementasi Kebijakan Negara Edisi Kedua. Jakarta: Bumi Aksara.

Writtig, A. 1977. Theory and Problems of Introduction to Psyshology. New York: McGrraw-Hill Book Company. 